\title{
The Relevance of the Informational Content of Book-Tax Differences for Predicting Future Income: Evidence from Latin American Countries
}

\author{
Alessandra Vieira Cunha Marques \\ Universidade Federal de Uberlândia, Faculdade de Ciências Contábeis, Uberlândia, MG, Brazil \\ Patrícia de Souza Costa \\ Universidade Federal de Uberlândia, Faculdade de Ciềncias Contábeis, Uberlândia, MG, Brazil \\ Pablo Rogers Silva \\ Universidade Federal de Uberlândia, Faculdade de Gestão e Negócios, Uberlândia, MG, Brazil \\ Received on 01:16.2015 - Desk Acceptance on 01.28.2015 - $3^{\text {rd }}$ version accepted on 08.05.2015.
}

\begin{abstract}
This study aims to investigate whether the different types of book-tax differences are useful for predicting the future income of publicly traded companies in five Latin American countries. This is possible since these differences convey information about transitory components of income, which can be used by investors for predicting future income. However, little is known about the relationship between tax variables and companies' future results. The sample analyzed here is composed of 580 publicly traded companies from five Latin American countries (Argentina, Brazil, Chile, Mexico, and Peru) with information available in the Economatica database covering 2002 to 2013. In terms of methodology, regressions are employed in order to find a connection between the different types (total, permanent, temporary, and the negative and positive variations) of book-tax differences and companies' current and future earnings per share, as well as some control variables suggested by previous literature. The model's coefficients were estimated through panel data techniques: fixed effects. The results obtained suggest that the information gathered in the different types of book-tax differences (total, permanent, temporary, positive and negative variations) is relevant in predicting future income. Total, permanent and temporary differences contribute to the uncertainty in future income prediction, given that results are more transitory and less persistent in years with higher book-tax differences. Positive and negative variations, on the other hand, attribute higher income in coming years to greater variations in book-tax differences, representing increased timeliness of results and a reduction in off balance sheet funding for the publicly traded companies from these countries.
\end{abstract}

Keywords: book-tax differences, relevance of accounting numbers, Latin America. 


\section{INTRODUCTION}

The information gathered in the differences between accounting income and taxable income - known as book-tax differences (BTDs) - can be useful for investors, analysts and creditors to forecast companies' future results (Lev \& Nissim 2004; Hanlon, 2005; Tang, 2006). This usefulness can be explained by the fact that BTDs are able to provide additional information about the transitory components of companies' current profits and of future cash flow. Yet, this usefulness is questioned, given that tax information is complex, incomplete and non standardized (Weber, 2009).

The usefulness of the information contained in the differences between accounting income and taxable income for economic agents can be demonstrated with the connection between BTDs and predicting future results. Generally, the greater the differences between accounting income and taxable income, the lower the estimates for future results (Tang, 2006). This negative relationship is justified by the fact that higher levels of BTDs mean that current profits are more transitory and less persistent, signaling poorer performance in following years (Tang, 2006).

In many jurisdictions, the information captured in BTDs is more relevant than the value of reported profit itself (Tang, 2006). The importance attributed to the differences between accounting income and taxable income can be explained by the fact that they offer information about the quality of profits reported, such as persistence, management aggressiveness, value relevance, and accounting conservatism (Hanlon, 2005; Heltzer, 2009; Blaylock, Shevlin, \& Wilson, 2012). Thus, BTDs can be useful for market participants when evaluating the quality of earnings reported.

Each type of BTD can result in different implications for predicting future results (Blaylock et al., 2012), namely: temporary BTDs present information regarding the persistence of companies' earnings and regarding earnings management (Hanlon, 2005); in turn permanent BTDs are suitable for identifying aggressive financial and tax reports - managing accounting income upwards and taxable income downwards (Frank, Lynch, \& Rego, 2009); and (positive and negative) variations in levels of BTDs show the levels of conditional and unconditional conservatism present in financial statements (Heltzer, 2009). Thus, each type of BTD can contribute in different ways to economic agents' uncertainty regarding companies' future results.

Furthermore, the connections between the different types of BTDs and future earnings forecasts cannot be taken as universal rules. Differences between legal syste$\mathrm{ms}$, demands for accounting information, differences in legal protection for external shareholders, and differences in degrees of financial and tax compliance (FTC) can have an impact on managers' accounting choices (Guenther \& Young, 2000), and, consequently, the usefulness of the accounting numbers released by companies. Thus, different types of BTDs can have different usefulness for investors in each country.

In scenarios with lower FTC, that is, in countries where accounting standards and tax rules are different, higher levels of BTDs (Hanlon, 2005) are verified, and accounting information is more relevant than tax information (Yoon, 2008). In scenarios with higher FTC, that is, in countries where accounting standards and tax rules are aligned, there are lower levels of BTDs and tax information is more highly valued by investors than reported accounting numbers (Yoon, 2008). Thus, the information gathered in BTDs can have different usefulness in each jurisdiction.

Institutional theory argues that companies tend to adopt practices that are institutionalized in society, with the intention of increasing their legitimacy in the market in which they operate, often without taking into consideration whether the accounting norms are or are not the most suitable (Meyer \& Rowan, 1977). Therefore, the types of BTDs that are relevant to investors estimating companies' future results in the United States may not be the same as those for Brazilian companies; this may be the result not only of the accounting practices adopted, but also of the investor culture and of the country's political system, among other features.

Thus, in the context of Latin American countries, known for high levels of FTC and developing capital markets (La Porta, De-Silanes, \& Shleifer, 2008), it is possible to find - for the usefulness of BTDs - different results from those obtained in previous studies. Faced with the context presented, this study investigates the types of book-tax differences that are relevant in forecasting future results in Latin American countries.

To do this, the connections between different types of BTDs (total, temporary, permanent, positive and negative) and future results forecasts for publicly traded companies in five countries in Latin America (Argentina, Brazil, Chile, Peru, and Mexico) were tested. In some studies (Hanlon, 2005; Ayers, Laplante, \& Mcguire, 2010; Costa, 2012), the relevance of total, temporary, permanent, positive and negative BTDs to economic agents was investigated separately; however, no studies have been found - until now - that conciliate all these types of BTDs into a single study, and particularly, with relation to the context of these five Latin American countries. Given that they are countries with their own peculiarities, they may exhibit different behaviors to those obtained in previous studies regarding the usefulness of different types of BTDs. The aim is thus to bridge this gap.

This study can contribute to literature on BTDs in providing international evidence regarding the implications of the differences between accounting norms and tax rules in the usefulness of financial statements for investors in various developing economies. Furthermore, it aims to build upon previous studies (Hanlon, 2005; Tang, 2006, 
2014), by providing evidence about which types of BTDs affect future results forecasts in some Latin American countries.

This study can also make a contribution for economic agents, since different types of BTDs are able to reveal information about the quality of companies' results. Thus, investors in firms in these Latin American countries could improve their own expectations regarding upcoming earnings with a more complete analysis of the information contained in BTDs.

Beyond this introduction, this study goes on to consider: the theoretical framework, with an emphasis on the relevance of the informational content of the accounting numbers in book-tax differences and in their types (section 2); the methodology used to carry out the empirical tests (section 3); the calculation and analysis of the results obtained (section 4); and the concluding remarks regarding the study (section 5).

\section{THEORETICAL FRAMEWORK}

\subsection{Book-Tax Differences}

Book-tax differences are defined as the differences between accounting income and taxable income. Accounting results can differ from taxable results due to at least three reasons, namely: firstly, due to the different purposes of the two forms of calculating results - one in accordance with generally accepted accounting principles (GAAP), with the aim of reducing information asymmetry, and the other designed to calculate taxable income, and obeying tax rules (Shackelford, Slemrod, \& Sallee, 2011).

The second reason accounting income and taxable income can be different is that whereas corporate accounting records the economic fundamentals of transactions in an objective and verifiable way, tax accounting is designed to induce or compensate individual behavior (Shackelford et al., 2011). For example, for accounting purposes, the value of company equipment is depreciated (an expense which reduces company results) each period, based on estimates for the useful lifespan of this asset. For taxation purposes, the value of this equipment is depreciated (reducing taxable income) each period in accordance with legal rules, without taking into consideration the real deterioration of the good. Due to this legal definition, depreciation for tax purposes will rarely be the same as the real depreciation estimate for equipment used for company purposes. Therefore, accounting results and taxable results may be different.

The third reason for BTDs is the fact that there are incentives to mislead both of the information recipients - financial market users and the government (Shackelford et al., 2011). The practice which affects profit reported to tax authorities, resulting in tax evasion activities, is known as tax management (Desai, 2005). This practice mostly consists of manipulating - downwards - taxable income (Frank et al., 2009). BTDs thus contain useful information about the quality of results reported by companies to the government.

The differences between accounting results and taxable results can affect the informational quality of financial statements and, consequently, their usefulness for users. Within the quality indicators of company results, value relevance, persistence of results, conditional conservatism and income smoothing are proxies that are able to show the reasons for the emergence of BTDs (Nakao, 2012). When companies report higher levels of BTDs, they have less persistent financial results (Hanlon, 2005; Tang, 2006), which justifies the fact that BTDs contribute to investor uncertainty regarding company accounting numbers.

\subsection{Relevance of Informational Content of Accounting Numbers}

Accounting numbers will be considered relevant if they have been used by investors, influencing them in their decision making (Barth, Beaver, \& Landsman, 2001). Thus, information contained in the differences between accounting income and taxable income is considered relevant if it assists investors in forecasting future results. This is possible since such differences not only provide information on transitory components of profit, but also on the predictability of future results and on company cash flow, that is, regarding the quality of profits (Hanlon, 2005; Tang, 2006). As these are some of the features of companies affected by BTDs, observing them may assist economic agents with regards to company evaluations (Hanlon, 2005).

Tang (2006) researched - using publicly traded Chinese company data - whether information gathered in BTDs could be used in order to evaluate forecasts for future income and for return on company shares; the author found a negative connection between BTD levels and earnings forecasts, suggesting that book-tax differences exhibit transitory components of current profit and of company cash flow. The uncertainty of possible reversals of these transitory components contributes to underestimating future results. Therefore, economic agents can use the information contained in BTDs to evaluate future company performance.

Ley and Nissam (2004) provide proof that BTDs are reflected in future company results; yet, given that investors have difficulty in incorporating the content of BTDs into their investment decisions, this information often goes unnoticed by economic agents. Similarly, Weber (2009) found that analysts also do not totally incorporate BTDs when making profit forecasts; the author even considers that there is variability between analysts with regards to the degree to with which they incorporate BTDs 
into their forecasts.

If differences between accounting income and taxable income can have an impact on companies' results, then an interpretation of the information gathered in BTDs may assist investors in forecasting future company results. The first study hypothesis emerges in light of this:

$\mathbf{H}_{\mathbf{1}}$ : The higher the level of total BTDs, the lower expectations are regarding future results for publicly traded companies in Latin America.

This hypothesis is reinforced by the results of the study by Hanlon (2005) carried out with data for companies from the United States, in which companies with higher levels of BTDs have less persistent future earnings than companies with smaller differences between accounting income and taxable income. Furthermore, in countries with higher financial and tax compliance, future results are less persistent and more weakly correlated with future cash flows (Atwood, Drake, \& Myers, 2010). The coupling of total BTDs with a history of greater links between accounting norms and tax rules in Latin American countries offers evidence that those companies - the subject of this study - with higher levels of BTDs will have lower performance in following years.

In order to improve the interpretation of the content of BTDs, it would be ideal to analyze them by type, given that separation provides additional information for investors. Each type of BTD offers different information about the quality of reported results (Tang \& Firth, 2012).

\subsection{Types of Book-Tax Differences}

A detailed understanding of the information contained in BTDs assists in analyzing the quality of current results and in forecasting future results. Earnings management and tax management practices can be revealed by analyzing the content of different types of BTDs (Comprix, Graham Jr., \& Moore, 2011). The consequences of such opportunistic management practices can compromise company cash flow, results for a period, and, consequently, investor confidence in companies (Hanlon, 2005; Blaylock et al., 2012). Thus, separating BTDs by type can make it possible for investors to make more precise inferences with regards to future company earnings.

Temporary and permanent BTDs can provide information that assists economic agents with their decision making regarding forecasts for future company results (Barth, Landsman, \& Lang, 2008). Permanent BTDs emerge when an economic event (revenue and/or expense) is identified for accounting purposes, but the tax rules impede recognition for tax purposes (Lev \& Nissim, 2004). Temporary differences, in turn, take place when an economic event is recognized with the same value for accounting and tax purposes, however at different moments.

Temporary BTDs originate from earnings management, from tax management and from differences between accounting standards and tax rules (Hanlon, 2005; Frank et al., 2009; Blaylock et al., 2012). As tax rules are inflexible when compared to GAAP, they result in greater positive temporary differences due to management dis- cretion in accounting practice choices for releasing financial reports (Blaylock et al., 2012).

Tax management, in turn, has the aim of delaying taxes by as long as possible, leading to greater levels of deferred tax expenses; however, unlike earnings management, it does not tend to be reversed the following year (Blaylock et al., 2012). Another motivation presented for the emergence of temporary BTDs simply derives from the differences between accounting norms and tax rules, in which managers make accounting choices without ulterior motives related to tax management and earnings management (Blaylock et al., 2012).

Hanlon (2005), in her analysis of the effects of higher temporary BTDS on future earnings and the persistence of accruals, claimed that discretionary accruals are less persistent than non discretionary ones. She also reported that companies with higher temporary BTDs present lower future earnings and less persistence of accruals, when compared to companies with lower BTDs. For the author, when accounting income is higher than taxable income, results are of poorer quality, that is, less persistent. According to this author, investors seem to correctly consider this informational content of temporary BTDs in weighing up the quality of reported profits. Thus, hypothesis $\mathrm{H}_{2}$ emerges for testing:

$\mathbf{H}_{2}$ : The higher the level of temporary BTDs, the lower the expectations regarding future results for publicly traded companies in Latin American countries.

It is expected, in the context of Latin American countries, that the higher the level of temporary BTDs, the lower future company results. Yet, each jurisdiction can exhibit different behaviors for this relationship, given that the relevance of the components of accounting information is strongly suggested by the level of influence of tax rules over accounting norms in each country (Yoon, 2008). Thus, if a country exhibits strong (weak) alignment of accounting norms with tax rules, this can result in accounting with low (high) informational quality.

Wilson (2009) used another type of BTD - permanent differences - to investigate the connection between tax planning, wealth generation for shareholders, and earnings management. This author found that the majority of cases of tax evasion significantly increase permanent BTDs for companies; that is, investors have created the belief that, if managers are willing to deceive tax authorities, they may also be willing to deceive investors (Hanlon \& Slemrod, 2009).

Thus, permanent differences are more strongly associated with market participant uncertainty regarding future company results than temporary differences (Comprix et al., 2011). This statement is reasonable because future reversals of deferred tax assets and of deferred tax liabilities (temporary BTDs) are more predictable than tax authorities accepting a tax account that gives rise to a permanent difference. In light of this, the third study hypothesis is presented:

$\mathbf{H}_{3}$ : The higher the level of permanent BTDs, the lower investor expectations regarding the future results of 
publicly traded companies in Latin American countries.

The signs of BTDs are also used by investors as an indicator of the quality of reported accounting numbers. The highest negative variations in BTDs signal a reduction in the quality of accounting numbers (Hanlon, 2005). Negative changes in BTDs can indicate that taxable income has increased with relation to accounting income, which alludes to the fact that companies have elevated tax accounts and lower future cash flow (Ayres et al., 2010). Companies with greater positive variations in BTDs also exhibit lower future results and company cash flow (Hanlon, 2005). Thus, both variations (positive and negative) in BTDs have an impact on forecasting accounting numbers.

The relationship between the sign of BTDs (positive and negative) was also studied by Heltzer (2009), who investigated the connection between the quality of accounting information - using accounting conservatism as a proxy for quality - and the signs of BTDs. This author showed that in years in which companies presented negative BTDs, they exhibited greater unconditional conservatism in accounting income and lower conditional and unconditional conservatism in taxable income. This fact points to a deterioration in the quality of results, since unconditional conservatism is related to earnings management practices (Qiang, 2007). This is due to companies less timely recognizing losses in accounting income.

In turn, in years with positive variations in BTDs, companies exhibit a decrease in conditional conservatism in financial statements, with relation to other years in the sample (Heltzer, 2009). In years in which companies present positive variations in BTDs, they exhibited an increase in timely recognition of earnings, or rather, a reduction in conditional conservatism, with relation to other years in the sample (Heltzer, 2009); however, this may be a sign of earnings management (Hanlon, 2005).

As well as investigating the signs (positive/negative) of BTDs, analysis of their variations is an important element in evaluating the quality of company results. So far as positive and negative changes in BTDs reveal information about the quality of results and about off balance sheet financing, such differences can be relevant for economic agents (Ayres et al., 2010).

Greater negative variations in BTDs can be indicators of a reduction in the quality of company results (Hanlon, 2005; Ayres et al., 2010). Since this involves situations in which taxable income has increased with relation to accounting income, it implies the fact that companies have higher tax accounts and lower available cash flow (Ayres et al., 2010). The greatest positive variations in BTDs can also be a sign of reductions in the quality of reported earnings and increases in off balance sheet financing, that is, accounting income has increased in relation to taxable income (Ayres et al., 2010).

Thus, to calculate whether positive and/or negative changes in BTDs influence forecasts for future results for publicly traded companies from Latin American countries, the fourth study hypothesis is presented:

$\mathbf{H}_{4}$ : There is an inversely proportional relationship between positive and negative variations in BTDs and future results for publicly traded companies from Latin American countries.

In light of this, it is believed that the higher the negative/positive variation in BTDs, the lower the forecast for future company results (Hanlon, 2005; Heltzer, 2009; Ayres et al., 2010), given that the greatest variations in BTDs have an impact on the quality of reported earnings.

\section{METHODOLOGY}

\subsection{Sample Selection Parameters and Collection of Data}

The subject population for this study consists of publicly traded companies from Latin American countries that traded their shares on the Stock Exchange between 2002 and 2013, and which have data available in the Economatica ${ }^{\circledast}$ database. Furthermore, countries that adopted International Financial Reporting Standard - compulsory for all publicly traded companies by 2012 - were selected, thus forming a sample with a single accounting standard.

Considering the population composed of twenty countries, eight were excluded for not compulsorily adopting IFRS for all publicly traded companies by 2012, and seven countries for not having available data in the Economática ${ }^{\circledast}$ database. This resulted in the final sample for this study, composed of five jurisdictions, namely: Argentina, Brazil, Chile, Mexico, and Peru, which together are responsible for approximately $78 \%$ of the total GDP for Latin America.
It is thus verified that the sample for this study represents the economy of the region in question, a fact that can warrant generalization of the results found for the five countries in the sample for the Latin American context.

Regarding the procedures used for selecting the companies that compose the final sample for this study - composed of 580 non financial publicly traded companies publicly traded companies with missing data and/or which did not have at least three consecutive values for the dependent variable EPS $_{\mathrm{it}+1}$, were excluded.

Consolidated annual accounting data covering 2002 to 2013 was used (considering 2002 and 2013 as bases) for listed companies with shares traded on the stock exchange on December 31, 2013. For listed companies with more than one type of share traded on the stock exchange, the information for the shares with greatest liquidity was taken into account. As each country in the sample has a different currency, the collection of data in standard currency, that 
is, the US dollar, was used as a parameter for this study.

\subsection{Empirical Models for Calculating Book-Tax Differences}

Five types of differences were used, which are: total (BTD), temporary (TEBDT), and permanent (PBTD), tested by Costa (2012), and positive and negative variations ( $\triangle \mathrm{BTD}$ ), tested by Ayers et al. (2010), and described below in Equations 1, 2, 3, and 4, respectively, with the intention of analyzing which of them may be relevant in forecasting future company results in Latin American countries.

$$
\begin{gathered}
B T D_{i t}=\frac{\left(P B I T_{i t}-T I\right)}{T A_{i t-1}} \\
T_{E B T D_{i t}}=\frac{\left(D I T / R_{i t}\right)}{T A_{i t-1}} \\
\text { PBTD }_{i t}=B T D_{i t}-\text { TEBTD }_{i t}
\end{gathered}
$$$$
\triangle B T D_{i t}=B T D_{i t}-B T D_{i t-1}
$$

In which:

$\mathrm{BTD}_{\text {it }}=$ total difference between accounting income and taxable income for company $\mathrm{i}$ in year $\mathrm{t}$; $\mathrm{PBIT}_{\mathrm{it}}=$ accounting profit before income tax for company i in year $\mathrm{t}$; $\mathrm{TI}_{\mathrm{it}}$ $=$ taxable income for company $\mathrm{i}$ in year $\mathrm{t}$; $\mathrm{TA}{ }_{\mathrm{it}-1}=$ total assets of company $\mathrm{i}$ in year t-1 (lagged assets); TEBTD $=$ temporary difference between accounting income and taxable income for company $\mathrm{i}$ in year $\mathrm{t} ; \mathrm{DIT}_{\mathrm{it}}=$ deferred income tax (profit and loss account) for company $\mathrm{i}$ in year $\mathrm{t} ; \mathrm{R}_{\mathrm{it}}=$ maximum income tax rate: Argentina (35\%), Brazil (34\%), Chile (20\%), Peru (30\%), and Mexico (33\%); PB$\mathrm{TD}_{\text {it }}=$ permanent difference between accounting income and taxable income for company $i$ in year $t ; \Delta \mathrm{BTD}_{\mathrm{it}}=$ is the value of the difference between BTD of company $i$ in year $t$ and BTD for company $i$ in year $t-1$. It shows whether the variation in BTDs was positive or negative from year $t$ to year $t-1$. All of the variables are pondered by total lagged assets.

Due to publicly traded companies' non disclosure of taxable income (TI) values (Hanlon, 2003; Costa, 2012), a proxy resulting from calculating the relationship between total income tax expenses (ITC) and the maximum income tax rate in the country $(R)$ was employed, as used by Hanlon (2005). For the five countries that are the subject of this study, information on TI was searched for in the financial statements published by the publicly traded companies; however, these companies did not report TI values. Accounting statements for 130 randomly selected publicly traded companies, covering 2002 to 2013, were analyzed.

Despite the fact that the effective rate (the ratio betwe- en income tax expenses and PBIT) can exhibit superior or inferior values to those of the maximum rate, there is evidence that the estimate for the taxable value - taking into consideration maximum income tax rates instead of companies' effective rates - does not significantly affect the results of the equation (Lev \& Nissim, 2004). This measure for taxable income has been used in some previous studies, such as in Hanlon (2005), Ayers et al. (2010), and Costa (2012).

The maximum rate of income tax is also used to calculate TEBTD. This difference is calculated by extrapolating deferred income tax (DIT) by the maximum rate. Thus, TEBTD is a proxy for the temporary difference between accounting income and taxable income. There is a limitation in the accounting norm for recognizing DIT, which can affect TEBTD calculations; the same occurs with the maximum rate, which may not represent the effective rate. However, this proxy was used by (Lev \& Nissim, 2004; Hanlon, 2005; Atwood et al., 2010; Nakao, 2012).

After calculating the components of BTDs, we proceed to the empirical regression model for forecasting future results. This model aims to investigate the effects of differences between accounting income and taxable income on the informational relevance of the accounting numbers reported, measured by future results. This model was developed from the methodology shown by Tang (2006), with the inclusion of control variables suggested in previous literature (Yoon, 2008; Costa, 2012).

The original regression model for future results proposed by Tang (2006) examines the content of BTDs for forecasting future earnings, as shown in Equation 5: 


$$
\mathrm{EPS}_{\mathrm{it}+1}=\beta_{0}+\beta_{1} \mathrm{EPS}_{\mathrm{it}}+\beta_{2} \mathrm{BTD}_{\mathrm{it}}+\varepsilon_{t+1}
$$

In which:

$\mathrm{EPS}_{\mathrm{it}+1}=$ value of net profit per share for company $\mathrm{i}$ in year $t+1$, scaled by the share price on April $30^{\text {th }}$, after the end of financial year $\mathrm{t}-1$; $\mathrm{EPS}_{\mathrm{it}}=$ value of net profit per share for company $i$ in year $t$, scaled by the share price on April $30^{\text {th }}$, after the end of financial year $t-1 ; \varepsilon^{t+1}=$ error term.

With Equation 6, the relationship between current earnings, the total, permanent, temporary, positive and negative types of BTDs, and some control variables, with future results forecasts for publicly traded companies in five Latin American countries, is investigated.

$$
\mathrm{EPS}_{\mathrm{it}+1}=\beta_{0}+\beta_{1} \mathrm{EPS}_{\mathrm{it}}+\beta_{2} \mathrm{X}_{\mathrm{it}}+\beta_{3} \mathrm{GFA}_{\mathrm{it}}+\beta_{4} \mathrm{NLTA}_{\mathrm{it}}+\beta_{5} \Delta \mathrm{BTM}_{\mathrm{it}}+\beta_{6} \mathrm{~L}_{i t}+\varepsilon_{t+1}
$$

In which:

$\mathrm{X}_{\mathrm{it}}=$ represents the independent variables total BTD, permanent PBTD, temporary TEBTD, positive and negative variations in BTDs (VNBTD = binary variable with value 1 for the variation from year $t$ to year $t+1$ in the BTD in the lowest quintile and 0 for the rest; VPBTD = binary variable with value 1 for the variation from year t to year $t+1$ in the BTD in the highest quintile and 0 for the rest); $\mathrm{GFA}_{\mathrm{it}}=$ level of fixed assets of company $\mathrm{i}$ in year $\mathrm{t}$ (gross fixed plus intangible assets scaled by total assets); NLTA $=$ Natural logarithm of total assets of company $i$ at the end of year $\mathrm{t}$ (indicates company size); $\Delta \mathrm{BTM}_{\mathrm{it}}=$ Variation in BTM ratio of company i from year $t-1$ to year $t$. Where $\mathrm{BTM}$ is the natural logarithm of the ratio between the accounting value of net equity (NE) of company i in year $t$ and the market value of the shares of company i in year t; $\mathrm{L}_{\mathrm{it}}=$ Variation in leverage of company $\mathrm{i}$ from year $\mathrm{t}-1$ to year t. $\mathrm{L}$ is calculated as long term debt deflated by total assets for year $\mathrm{t}-1 ; \varepsilon_{\mathrm{t}+1}=$ error term.

The Chow, Lagrange Multiplier (LM) and Breusch-Pagan tests are used to choose the most suitable regression model to be used for the study data.

\subsection{Descriptive Statistics}

In Table 1 the descriptive statistics for the continuous variables from the future results forecast model for the five Latin American countries which compose the proposed selection are presented. The total sample for this study is composed of 5,800 observations $(\mathrm{N} x \mathrm{~T})$ and a sample without outliers $(\mathrm{N} x \mathrm{~T}=5,065)$. As the distribution of future results in this study was very volatile, the sample without outliers was chosen to work with, according to standard deviation.

\begin{tabular}{|c|c|c|c|c|c|c|}
\hline Jurisdiçtion & Variable & Obs & Average & Standard Deviation & Minimum & Maximum \\
\hline \multirow{8}{*}{ Latin America } & EPSit+1 & 4,671 & 0.237 & 1.924 & -42.52 & 32.49 \\
\hline & EPSit & 4,689 & 0.215 & 1.927 & -41.000 & 28.596 \\
\hline & BTD & 5,029 & 0.008 & 0.146 & -6.889 & 1.742 \\
\hline & TEBTD & 3,330 & -0.002 & 0.064 & -0.965 & 0.904 \\
\hline & GFA & 5,185 & 0.488 & 0.644 & 0.00 & 31.446 \\
\hline & NLTA & 5,310 & 13.141 & 1.881 & 2.397 & 19.684 \\
\hline & $\triangle \mathrm{BTM}$ & 4,590 & -0.041 & 0.635 & -4.895 & 4.601 \\
\hline & $\mathrm{L}$ & 5,134 & -0.025 & 0.340 & -7.882 & 8.345 \\
\hline
\end{tabular}

$\mathrm{EPS}_{\mathrm{it}+1}=$ logarithm of net profit per share for company $\mathrm{i}$ in year $\mathrm{t}+1$, scaled by the share price on April $30^{\text {th }}$, after the end of financial year $\mathrm{t}-1$; $\mathrm{EPS}_{\mathrm{it}}=\mathrm{logarithm}_{\mathrm{i}}$ of net profit per share for company $\mathrm{i}$ in year $\mathrm{t}$, scaled by the share price on April $30^{\text {th }}$, after the end of financial year $\mathrm{t}-1$; BTD $=\mathrm{BTD}$ calculated as the total difference between accounting income and taxable income; TEBTD = temporary BTD; PBTD = permanent BTD; NLTA = natural logarithm of total assets of company i in year $\mathrm{t}$; $\mathrm{BTM}_{\mathrm{it}}$ $=$ Variation in BTM ratio of company $\mathrm{i}$ from year $\mathrm{t}-1$ to year $\mathrm{t}$. BTM = natural logarithm of the ratio between the accounting value of NE and the market value of the shares of company $\mathrm{i}$ in year $\mathrm{t} \mathrm{L}=$ Variation in leverage calculated as long term debt deflated by total assets of company $\mathrm{i}$ in year $\mathrm{t}-1$.

Source: Prepared by the authors. 
To exclude the outliers, calculations of the $d$ fits statistics for each standardized residual were used and the cut-off points suggested by Baum (2006), whose criteria involves excluding those observations with $\mid$ difts $\mid>2.0$ $(\mathrm{k} / \mathrm{N})^{1 / 5}$, were adopted, in which $\mathrm{k}=$ number of parameters in the model, and $\mathrm{N}=$ number of observations. The averages and standard deviations for BTD, TEBTD and PBTD are close to zero, given that they were scaled by lagged total assets and represent a percentage of these assets. The values found for the average BTD (0.008) for Latin America are close to those found by Tang (2006) for the Chinese capital market $(-0.010)$, as well as by Wilson (2009) and by Costa (2012) for Brazil (-0.02 and 0.007 , respectively).

The values found for the average TEBTDs $(-0.002)$ for Latin America were close to those shown by Hanlon (2005) for the US market (0.001) and by Costa (2012) for Brazil (-0.006). For the average PBTDs, values close $(0.010)$ to those shown in previous literature were also found. Comprix et al. (2011) showed an average of 0.02 and Costa (2012) found an average of 0.012 in the Brazilian capital market.

Table 1 exhibits the average for the dependent variable $\mathrm{EPS}_{\mathrm{it}+1}(0.237)$ and for the independent variable EPS $_{\text {it }}(0.215)$; it is found that, on average, the future results of publicly traded companies from the five Latin American countries are greater than the current results. In the Chinese stock market, on the other hand, current earnings have a higher average (0.038) than future earnings (0.029), as indicated by Tang (2006). As total assets represent company size (in this study, the log of total assets), it is verified in Table 1 that the average size of companies in Latin American countries is 13.141. The average for the $\triangle \mathrm{BTM}$ variable in Latin America is -0.041 , suggesting that the market value is greater than the accounting value of net equity for these companies.

In Table 2, the proportions of the binary variables of the models are presented.

Table 2

Proportion of binary variables

\begin{tabular}{|c|c|c|c|c|}
\hline Variable & Description & & N. Obs & $\%$ Obs \\
\hline \multirow{3}{*}{ VNBTD } & 0 & remaining $\Delta$ in BTD & 4,109 & $81.67 \%$ \\
\hline & 1 & $\Delta$ in BTD in lowest quintile & 922 & $18.33 \%$ \\
\hline & & Total & 5,031 & $100 \%$ \\
\hline \multirow{3}{*}{ VPBTD } & 0 & remaining $\Delta$ in BTD & 4,753 & $94.51 \%$ \\
\hline & 1 & $\Delta$ in BTD in highest quintile & 276 & $5.49 \%$ \\
\hline & & Total & 5,029 & $100 \%$ \\
\hline
\end{tabular}

VNBTD = binary variable with value 1 for the variation from year $t$ to year $t+1$ in the BTD in the lowest quintile and 0 for the rest; VPBTD = binary variable with value 1 for the variation from year $t$ to year $t+1$ in the BTD in the highest quintile and 0 for the rest.

Source: Prepared by the authors.

According to Ayres et al. (2010), changes in the signs of the BTDs have an influence on the relevance of accounting numbers for external users. It is verified that $18.33 \%$ of the companies in the study sample exhibited a negative variation in the lowest quintile of BTDs and $5.49 \%$ exhibited positive variations in the highest quintile of BTDs. In both cases of variations of BTDs, they can be interpreted as a loss in the quality of earnings (Hanlon, 2005; Ayres et al., 2010).

\subsection{Empirical Results for the Future Results Forecasting Model}

The choice between analytical models for panel data was carried out via the Chow, Breusch-Pagan Lagrange Multiplier (LM), and Hausman tests. The results presented in Table 3 show that the suitable estimating technique for the coefficients is the fixed effects model for analyzing the five Latin American countries together.

\begin{tabular}{|c|c|c|c|c|}
\hline \multirow{2}{*}{ Country } & Breusch-Pagan & Hausman & Chow & Suitable \\
\hline & Chi2 & Chi2 & $F$ & Specification \\
\hline Equation 1 & $1.95^{*}$ & $226.61^{* * *}$ & $1.43^{* * *}$ & Fixed Effect \\
\hline Equation 2 & 0.00 & $147.03^{* * *}$ & $1.15^{* *}$ & Fixed Effect \\
\hline Equation 3 & 0.04 & $193.07^{* * *}$ & $1.29 * * *$ & Fixed Effect \\
\hline
\end{tabular}

${ }^{*} \mathrm{p}<10 \%$; $* * \mathrm{p}<5 \%$; ** $\mathrm{p}<1 \%$. Equation 1 = using the total BTD type; Equation 2 = using the temporary and permanent BTD type; Equation $3=$ using the negative and positive BTD type.

Source: Prepared by the authors. 
The results from the regression models based on total BTDs (Table 4) provide statistical evidence from the F test equal to 33.85 , with a $1 \%$ degree of statistical significance, suggesting that the average for all of the regressors together cannot be equal to zero. Thus, the independent variables seem to contribute to future results forecasts.

Table $4 \quad$ Results for the Future Results Forecasting Model and Total BTD

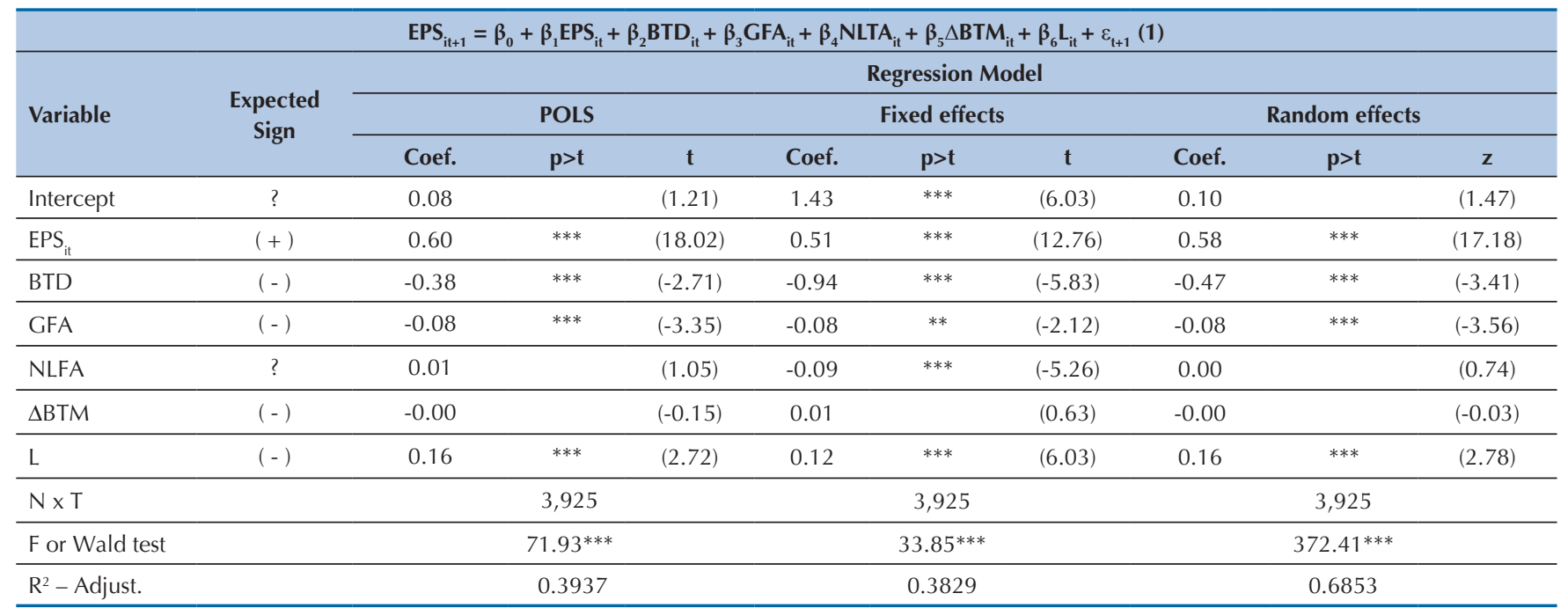

$* \mathrm{p}<10 \%$;* $\mathrm{p}<5 \%$; ** $\mathrm{p}<1 \%$. EPS $=$ net profit per share for company $\mathrm{i}$ in year $\mathrm{t}+1$, scaled by the share price on April $30^{\text {th }}$, after the end of financial year $\mathrm{t}-1 ; \mathrm{EPS}$. $=$ net profit per share for company $\mathrm{i}$ in year $\mathrm{t}$, scaled by the share price on April $30^{\text {th }}$, after the end of financial year $\mathrm{t}-1$; $\mathrm{BTD}=$ book-tax differences calculated as the total difference between accounting income and taxable income; GFA = gross fixed and intangible assets scaled by lagged total assets; NLTA = natural logarithm of total assets of company $\mathrm{i}$ in year $\mathrm{t} ; \mathrm{BTM}=$ Variation in BTM ratio of company $\mathrm{i}$ from year $\mathrm{t}-1$ to year $\mathrm{t}$. BTM = natural logarithm of the ratio between the accounting value of $\mathrm{NE}$ and the market value of the shares of company $\mathrm{i}$ in year $\mathrm{t}$; $\mathrm{L}=$ Company leverage calculated as long term debt deflated by total assets of company $\mathrm{i}$ in year $\mathrm{t}-1$. Source: Prepared by the authors.

The findings for the model that looks for the connection between total BTDs and future results forecasts - for Latin American countries - shows that the EPS it $_{\text {va- }}$ riable exhibits a positive sign (as expected) and with statistical significance (1\%). In other words, current results for publicly traded companies from some Latin American countries may influence investors in forecasting future results. These findings are similar to those of Tang (2006), in which current results are positively associated with future results in the context of the Chinese capital market. The BTD variable exhibits a negative sign and statistical significance $(\mathrm{p}<0.01)$, as expected for Hypothesis $\mathrm{H}_{1}$ in this study.

Thus, the BTDs of companies from Latin American countries suggest that the current profits of these companies are more transitory and less persistent in years with greater levels of BTDs (Tang, 2006) and, therefore, worse performance may be expected for years following greater levels of BTDs. Consequently, hypothesis $\mathrm{H}_{1}$ is accepted: the higher the level of total BTD, the lower the expectations regarding future results for publicly traded companies from Latin America.

In some jurisdictions, such as in China, information gathered in BTDs is more relevant than the result reported to investors itself (Tang, 2006). The results found - and mentioned in the previous paragraph - in the context of Latin America suggest that both current results as well as total BTDs are relevant for investors in forecasting upcoming company results.

Furthermore, in these Latin American countries in which there is a history of greater financial and tax compliance (FTC), the components of accounting information - such as GFA, NLTA, and L - may be useful for forecasting future results, as shown in Table 4, considering that the results for these variables present statistical significance. Therefore, the greater the amount of company fixed assets, the lower the forecast for future income, which may represent an interpretation by investors that the higher the level of investment in fixed assets, the greater depreciation expenses and, consequently, the lower company results.

Company size is negatively associated with the forecasting of results $(\mathrm{p}<0.01)$, that is, shareholders interpret that the bigger the company, the lower the forecast for future company results. These results are consistent with the claim of Cullinan (1999) that companies tend to make accounting choices motivated by size because they seek to reduce their political costs. The leverage variable represents a positive (contrary to that expected) and statistically significant connection with current earnings forecasts, that is, the greater company leverage, the greater the expectations regarding future company results.

The control variable $\triangle \mathrm{BTM}$ exhibits a different sign to that expected (a positive sign), yet does not exhibit statistical significance. The positive and statistically significant coefficient for this variable indicates an increase in information asymmetry between investors and companies. In the context of these five Latin American countries, no inferences can be made regarding the use of this information by investors. 
The results shown in Table 4 partially confirm the findings of Yoon (2008), when he compared the relevance of accounting information between countries considered to have low FTC and those considered to have high FTC; in those with high FTC, variations in sales, depreciation expenses, and tax values are less relevant for users of financial statements when compared with countries with low FTC (Yoon, 2008). Faced with the assumption that managers are more likely to make decisions, with the intention of trying to reduce their tax expenses, in contexts with high FTC, the biggest aim would be to reduce taxation, and not the relevant information that reflects in expectations for future results (Yoon, 2008). In the five Latin American countries that are the subject of this study, both tax information as well as accounting information is relevant for investors.
The results for the connection between the permanent and temporary types of BTD with future results forecasts - for the companies from Latin American countries - are presented in Table 5. For this regression model, it is also verified that the independent variables are related to the dependent variable EPSt+1, given that the F test presents statistical significance ( $p$-value $<0.01$ ).

It is verified in Table 5 that current earnings are positively associated with the future results for companies from these Latin American countries, in accordance with Tang (2006). It is found that a statistically significant association exists between the temporary and permanent types of BTDs and forecasts for future company results, confirming within the context studied here the results found previously (Hanlon, 2005; Yoon, 2008; Blaylock et al., 2012).

Table 5 Results for Future Results Forecasting Model and Temporary and Permanent BTD

\begin{tabular}{|c|c|c|c|c|c|c|c|c|c|c|}
\hline \multicolumn{11}{|c|}{ EPS $_{\mathrm{it}+1}=\beta_{0}+\beta_{1} \mathrm{EPS}_{\mathrm{it}}+\beta_{2}$ TEBTD $_{\mathrm{it}}+\beta_{3}$ PBTD $_{\mathrm{it}}+\beta_{4} \mathrm{GFA}_{\mathrm{it}}+\beta_{5} \mathrm{NLTA}_{\mathrm{it}}+\beta_{6} \Delta \mathrm{BTM}_{\mathrm{it}}+\beta_{7} \mathrm{~L}_{\mathrm{it}}+\varepsilon_{\mathrm{t}+1}(2)$} \\
\hline \multirow{3}{*}{ Variable } & \multirow{3}{*}{$\begin{array}{l}\text { Expected } \\
\text { Sign }\end{array}$} & \multicolumn{9}{|c|}{ Regression Models } \\
\hline & & \multicolumn{3}{|c|}{ POLS } & \multicolumn{3}{|c|}{ Fixed effects } & \multicolumn{3}{|c|}{ Random effects } \\
\hline & & Coef. & $p>t$ & $t$ & Coef. & $p>t$ & $t$ & Coef. & $p>t$ & $\mathbf{z}$ \\
\hline Intercept & $?$ & 0.06 & & $(0.32)$ & 1.77 & $* * *$ & $(6.50)$ & 0.06 & & $(1.00)$ \\
\hline $\mathrm{EPS}_{\text {it }}$ & $(+)$ & 0.64 & $* * *$ & $(0.98)$ & 0.58 & $* * *$ & $(15.11)$ & 0.64 & $* * *$ & $(21.30)$ \\
\hline PBTD & $(-)$ & -0.55 & $* * *$ & $(0.32)$ & -1.22 & $* * *$ & $(-6.36)$ & -0.55 & $* * *$ & $(-3.68)$ \\
\hline GFA & $(-)$ & -0.05 & $* *$ & $(0.32)$ & -0.02 & & $(-0.59)$ & -0.05 & $* *$ & $(-2.40)$ \\
\hline NLTA & $?$ & 0.00 & & $(0.37)$ & -0.12 & $* * *$ & $(-6.03)$ & 0.00 & & $(0.81)$ \\
\hline$\Delta \mathrm{BTM}$ & $(-)$ & -0.01 & & $(0.45)$ & -0.01 & & $(-0.42)$ & -0.02 & & $(-0.97)$ \\
\hline $\mathrm{L}$ & $(-)$ & 0.13 & $* * *$ & $(0.32)$ & 0.11 & $* *$ & $(2.10)$ & 0.14 & $* *$ & $(2.59)$ \\
\hline F or Wald & & & $72.16^{* * *}$ & & & $36.11^{* * *}$ & & & $505.14^{* * *}$ & \\
\hline $\mathrm{R}^{2}-$ Adjust. & & & 0.4594 & & & 0.2510 & & & 0.6402 & \\
\hline
\end{tabular}

$* \mathrm{p}<10 \%$;* $\mathrm{p}<5 \%$; ${ }^{* *} \mathrm{p}<1 \%$. EPS $\mathrm{it+1}_{2}=$ net profit per share for company $\mathrm{i}$ in year $\mathrm{t}+1$, scaled by the share price on April $30^{\text {th }}$, after the end of financial year $\mathrm{t}-1$; $\mathrm{EPS}=$ net profit per share for company $\mathrm{i}$ in year $\mathrm{t}$, scaled by the share price on April $30^{\text {th }}$, after the end of financial year $\mathrm{t}-1$; TEBTD $=$ temporary $\mathrm{BTD} ; \mathrm{PBTD}=$ permanent BTD; GFA = gross fixed and intangible assets scaled by lagged total assets; NLTA = natural logarithm of total assets of company $\mathrm{i}$ in year $\mathrm{t} ; \triangle \mathrm{BTM}=$ variation in BTM ratio of company $\mathrm{i}$ from year $\mathrm{t}-1$ to year $\mathrm{t}$. BTM = natural logarithm of the ratio between the accounting value of $\mathrm{NE}$ and the market value of the shares of company $\mathrm{i}$ in year $\mathrm{t} ; \mathrm{L}=$ company leverage calculated as long term debt deflated by total assets of company $\mathrm{i}$ in year $\mathrm{t}-1$. Source: Prepared by the authors.

With regards to temporary BTDs, the results suggest that, the greater the level of this type of BTD, the less persistent these Latin American companies' future results will be and, consequently, the greater the uncertainty regarding future results. These results offer evidence that such differences can originate from discretionary accruals, since, according to Blaylock et al. (2012), and also to Hanlon (2005), they are less persistent and more likely to be reversed in subsequent periods, thus affecting company results.

It is also important to highlight that as future results are less persistent in the context of these Latin American countries, (that is, the greater the TEBTDs, the lower the
$\left.\mathrm{EPS}_{\mathrm{it}+1}\right)$, the temporary differences may derive from earnings management and not tax management. According to Blaylock et AL. (2012), companies with higher temporary BTDs arising from earnings management exhibit lower future results. One fact not captured by the estimate models and not presented in the results, but which is important to mention, is that the obligation of IFRS in Latin American countries may be having an impact on BTDs. In the temporary case, for example, there was an increase in Brazil (Mann-Whitney $=-2.567$; $\mathrm{p}$-value $=0.01$ ) and marginally in Peru (Mann-Whitney $=1.771 ; \mathrm{p}$-value $=$ 0.07). Some statistical differences were also found with relation to total and permanent BTDs in Brazil, Peru, and 
Chile, before and after IFRS.

Given the results presented for the temporary BTDs, Hypothesis $\mathrm{H}_{2}$ of this study is accepted, which is: the greater the level of temporary BTDs, the lower expectations regarding future results for publicly traded companies in Latin America. It is inferred that the greater the amount of temporary differences, the less persistent the future results of companies in Argentina, Brazil, Chile, Peru and Mexico.

With regards to permanent BTDs, the coefficient exhibits a negative (as expected) and statistically significant (p-value $<0.01$ ) sign, which may be indicative that they have an impact on future company results. This uncertainty may be a reflection of the greater discretion allowed for managers in these cases, considering that they can incorporate non-taxable revenue and non-deductable expenses for income tax purposes into accounting results. Furthermore, cases of tax evasion increase the level of PBTDs (Wilson, 2009) and consequently, the risk of companies being penalized, which would compromise future company results.

However, a stronger connection for the permanent type of BTD when compared to temporary BTDs (both p-value $<0.01)$ with forecasts for future company results was not identified, contradicting the prediction of Comprix et al. (2011). With the results presented, Hypothesis $\mathrm{H}_{3}$ is accepted, which claims that the higher the level of permanent BTDs, the lower the expectations regarding future results for publicly traded com- panies from Latin American countries.

For the control variables in the study, statistical significances were found in the context of publicly traded companies from Latin American countries only for size (NLTA) and leverage (Table 5). The greater the size of companies from these Latin American countries that compose the sample, the lower their future results will be, as indicated by Cullinan (1999) and also by Costa, Silva and Laurencel (2013). The results for leverage show that higher company debt contributes to market uncertainty, in accordance with prior literature from Ayres et al. (2010).

With analysis of the data from Table 6 , it is verified that the panel data technique is indicated for the regression with the positive and negative BTD variables in the context of Latin America, since the F test and Wald Test exhibit strong statistical significance (p-value $<0.01)$. The variable coefficients, presented in Table 6, show that the variables from this study are associated with future results, except $\triangle B T M$ which did not exhibit statistical significance. These results are consistent with those of Yoon (2008), in concluding that the tax elements in financial statements are relevant in countries with higher FTC. Current earnings are positively associated with the future results of companies from some Latin American countries (p-value $<0.01$ ), that is, the higher current results, the higher future company results, thus confirming the findings of Tang (2006).

Table 6 Results for Future Results Forecasting Model and Positive and Negative BTD

\begin{tabular}{|c|c|c|c|c|c|c|c|c|c|c|}
\hline \multicolumn{11}{|c|}{$\mathrm{EPS}_{\mathrm{it}+1}=\beta_{0}+\beta_{1} \mathrm{EPS}_{\mathrm{it}}+\beta_{2} \mathrm{VNBTD}_{\mathrm{it}}+\beta_{3} \mathrm{VPBTD}_{\mathrm{it}}+\beta_{4} \mathrm{GFA}_{\mathrm{it}}+\beta_{5} \mathrm{NLTA}_{\mathrm{it}}+\beta_{6} \Delta \mathrm{BTM}_{\mathrm{it}}+\beta_{7} \mathrm{~L}_{\mathrm{it}}+\varepsilon_{\mathrm{t}+1}(3)$} \\
\hline \multirow{3}{*}{ Variable } & \multirow{3}{*}{$\begin{array}{l}\text { Expected } \\
\text { Sign }\end{array}$} & \multicolumn{9}{|c|}{ Regression Models } \\
\hline & & \multicolumn{3}{|c|}{ POLS } & \multicolumn{3}{|c|}{ Fixed effects } & \multicolumn{3}{|c|}{ Random effects } \\
\hline & & Coef. & $p>t$ & $\mathrm{t}$ & Coef. & $p>t$ & t & Coef. & $p>t$ & $\mathbf{z}$ \\
\hline Intercept & ? & 0.09 & & $(6.10)$ & 1.48 & *** & $(6.10)$ & 0.11 & & $(1.06)$ \\
\hline $\mathrm{EPS}_{\mathrm{it}}$ & $(+)$ & 0.58 & $* * *$ & $(11.52)$ & 0.48 & $* * *$ & $(11.52)$ & 0.56 & $* * *$ & $(0.74)$ \\
\hline VNBTD & $(-)$ & -0.01 & & $(2.93)$ & 0.07 & *** & $(2.93)$ & 0.00 & & $(-0.95)$ \\
\hline VPBTD & $(-)$ & 0.12 & $* * *$ & $(2.68)$ & 0.09 & $* * *$ & $(2.68)$ & 0.12 & $* * *$ & $(-1.06)$ \\
\hline GFA & $(-)$ & -0.07 & $* * *$ & $(-2.01)$ & -0.08 & $* *$ & $(-2.01)$ & -0.08 & $* * *$ & $(-1.03)$ \\
\hline NLTA & $?$ & 0.00 & & $(-5.45)$ & -0.09 & $* * *$ & $(-5.45)$ & 0.00 & & $(-1.06)$ \\
\hline$\Delta \mathrm{BTM}$ & $(-)$ & -0.00 & & $(0.73)$ & 0.01 & & $(0.73)$ & 0.00 & & (1.03) \\
\hline L & $(-)$ & 0.17 & $* * *$ & $(2.30)$ & 0.14 & $* *$ & $(2.30)$ & 0.17 & $* * *$ & $(-0.13)$ \\
\hline $\mathrm{N} \times \mathrm{T}$ & & & 3,930 & & & 3,930 & & & 3,930 & \\
\hline For Wald test & & & $76.75^{* * *}$ & & & $29.73^{* * *}$ & & & $476.13^{* * *}$ & \\
\hline $\mathrm{R}^{2}$ & & & 0.3899 & & & 0.2545 & & & 0.2458 & \\
\hline
\end{tabular}

$* \mathrm{p}<10 \% ; * * \mathrm{p}<5 \%$; ** $\mathrm{p}<1 \%$. EPS ${ }_{\mathrm{it}+1}=$ net profit per share for company $\mathrm{i}$ in year $\mathrm{t}+1$, scaled by the share price on April $30^{\text {th }}$, after the end of financial year $\mathrm{t}-1$; $\mathrm{EPS}_{\mathrm{it}}=$ net profit per share for company $\mathrm{i}$ in year $\mathrm{t}$, scaled by the share price on April $30^{\text {th }}$, after the end of financial year $\mathrm{t}-1$; $\mathrm{VNBTD}=$ binary variable with value 1 for the variation from year $\mathrm{t}$ to year $\mathrm{t}+1$ in the $\mathrm{BTD}$ in the lowest quintile and 0 for the rest; VPBTD = binary variable with value 1 for the variation from year $\mathrm{t}$ to year $\mathrm{t}+1$ in the BTD in the highest quintile and 0 for the rest; GFA = gross fixed and intangible assets scaled by lagged total assets; NLTA = natural logarithm of total assets of company $i$ at the end of year $t, \triangle B T M=$ variation in BTM ratio of company $i$ from year $t-1$ to year $t$; BTM = natural logarithm of the ratio between the accounting value of $\mathrm{NE}$ and the market value of the shares of company $\mathrm{i}$ in year $\mathrm{t} ; \mathrm{L}=$ company leverage calculated as long term debt deflated by total assets of company $\mathrm{i}$ in year $\mathrm{t}-1$ Source: Developed by the authors.

The positive coefficient for the VPBTD variable, contrary to expected, shows that the greater the positive variation in BTDs (that is, higher accounting income than taxable income), the higher future results will be for publicly traded companies from Latin American countries. The positive coefficient for VPBTD suggests more timely 
results, which may be evidence of lower conditional conservatism in financial statements, which is consistent with research carried out by Heltzer (2009); and contrary to the conjecture - proposed by Hanlon (2005), by Ayres et al. (2010), and by Tang and Firth (2012) - that large positive variations in BTDs are related to lower upcoming earnings.

Thus, since the results for VPBTD are inconsistent with Hypothesis $\mathrm{H}_{4}$ - that there is an inversely proportional relationship between a positive sign for BTDs and the future results of publicly traded Latin American countries - this hypothesis is rejected.

The positive results exhibited for the VNBTD variable coefficient suggest that in years with large negative variations in BTDs (that is, taxable income higher than accounting income), investors in Latin American companies may overestimate company results. A positive sign for VNBTD may be a sign of a reduction in off balance sheet financing (Ayres et al., 2010), seen as something that is positive for companies. These discoveries constitute a surprise, given that Hanlon (2005) found contrary results when researching data from American companies. The greater the negative variation in BTDs, the lower the forecast for upcoming company results (Hanlon, 2005; Ayres et al., 2010).

The rest of the control variables also exhibit statistical significance, except for $\triangle \mathrm{BTM}$, showing that in this regression model with positive and negative BTDs, they should be used - by investors and analysts of Latin American companies - for forecasting future results. The amount of fixed assets of publicly traded companies from some Latin American countries is negatively associated with future results ( $\mathrm{p}$-value $<0.01$ ), confirming the previous assumption that greater investment in fixed assets results in higher depreciation, depletion and amortization expenses; higher levels of expenses can result in lower company results.

Company size (NLTA) also exhibits the expected coefficient (negative) p-value $<0.01$; thus, it can be inferred that the bigger the publicly traded Latin American company, which compose the study sample, the lower future results are. These results show that the accounting choices of managers at the Latin American companies are motivated by company size, in accordance with Jaafar and McLeay (2007).

The positive coefficient exhibited for the leverage variable ( $\mathrm{p}$-value $<0.05$ ) suggests that the higher the level of debt of the companies in the sample, the higher future company results. Ayres et al. (2010) argue that, the more leveraged companies are, the greater economic agents' mistrust with relation to the company.

It can be inferred that the total, permanent, temporary, positive and negative BTD types are used by economic agents for forecasting the future results of publicly traded companies from five Latin American countries, as shown in Table 7 .

Table 7 Overview of the relationship between hypotheses, variables, expected signs and signs found

\begin{tabular}{|c|c|c|c|c|}
\hline Hypothesis & Connection & Result & Expected sign & Sign found \\
\hline $\mathrm{H}_{1}$ & Total BTD and EPS $\mathrm{EP}_{\mathrm{it}+1}$ & Accepted & $(-)$ & $(-)$ \\
\hline $\mathrm{H}_{2}$ & Temporary BTD and EPS $\mathrm{EP}_{\mathrm{it}+1}$ & Accepted & $(-)$ & $(-)$ \\
\hline $\mathrm{H}_{3}$ & Permanent BTD and EPS $\mathrm{Et}_{\mathrm{it}+1}$ & Accepted & $(-)$ & $(-)$ \\
\hline \multirow{2}{*}{$\mathrm{H}_{4}$} & Positive BTD and EPS ${ }_{i t+1}$ & Rejected & $(-)$ & $(+)$ \\
\hline & Negative BTD and EPS ${ }_{\mathrm{it}+1}$ & Rejected & $(-)$ & $(+)$ \\
\hline
\end{tabular}

Source: Prepared by the authors.

It is important to highlight that, in Latin American countries - even with a history of greater financial and tax compliance, with accounting indirectly regulated by the government, and the stock market exhibiting weak investor protection - the information gathered in BTDs is relevant for forecasting future results.

\section{CONCLUDING REMARKS}

This study investigates the usefulness of different types of BTDs for forecasting the future results of companies from the stock markets of five Latin American countries (Argentina, Brazil, Chile, Mexico, and Peru). Previous literature suggests that the tax information contained in financial statements provides clues regarding the companies' future earnings and cash flow. Yet, the results are contradictory, since there is no consensus as to whether BTDs are used and which types of BTDs are used by economic agents in company evaluations.

Until now, no studies have been found that investigate the subject in the context of Latin American countries, altogether. This concerns a region with a capital market with weak investor protection, government interference in issuing accounting rules and with a history of greater financial and tax compliance. Thus, it is understood that 
these countries provide an environment which is favorable for testing the hypotheses of this study. Furthermore, as these countries have their own peculiar characteristics, they may present different results to previous studies regarding BTDs.

The results found provide evidence that the total, temporary, and permanent types of BTDs and positive and negative variations in them may be relevant for investors in publicly traded companies in these five Latin American countries for forecasting future results. The total, temporary, and permanent types of BTDs exhibit negative coefficients for the relationship with future results forecasts, which is consistent with hypotheses $\mathrm{H}_{1}$, $\mathrm{H}_{2}$ e $\mathrm{H}_{3}$. Thus, it can be inferred that, the greater the levels of these types of BTDs, the lower the future results of the publicly traded companies analyzed.

There is evidence that the current profits of the publicly traded companies from the five Latin American countries are more transitory and less persistent in years with higher BTDs; thus, weaker performance can be expected for years following periods with greater levels of BTDs. It is suggested that the temporary BTDs of the companies that are the subject of this study may originate from earnings management, given that the companies exhibit lower future results in years with greater temporary BTDs arising from this management practice. As a higher level of permanent BTDs is an indicator of tax evasion activities, it is suggested that, in years with greater amounts of permanent BTDs, they can be interpreted as tax management activity and, consequently, deterioration in the quality of the accounting numbers reported.

The positive and negative variations in BTDs exhibit positive coefficients, contrary to expected. The positive coefficient for the positive variations in BTDs may be a sign of increased timeliness in results and less conditional conservatism in the financial statements of publicly traded companies from Latin American countries. The positive coefficient for the negative variations in BTDs, in turn, may represent a reduction in off balance sheet financing at these institutions from Latin American countries, which would be seen as positive information regarding company results. Thus, there is evidence that the greater the variations in BTDs, the higher the companies' future results, and, therefore, hypothesis $\mathrm{H}_{4}$ is rejected.

It should still be noted that the available database prevents inference of the results for all Latin American countries, given that of the 20 countries in this region, only five have public data available the Economatica ${ }^{\circ}$ system. Another important question arises from the fact that the share prices on April $30^{\text {th }}$, after the end of the financial year $\mathrm{t}-1$, may not reflect the impact of BTDs, since they are affected by a multifaceted set of factors that were not predicted in the models estimated. Despite structured panel data with models estimated for fixed effects, which control the variables that are constant with time (individual differences), being used, even still, the lack of an inclusion of capital structure and corporate governance factors (which can change with time), for example, may skew the results.

Another limitation of this study regards the estimation for the calculation of BTDs, primarily the TI calculation. TI was estimated via extrapolation of current income tax expense and the maximum tax rate; it is not the ideal measure, since it contains measurement errors, but it is the information available to economic agents. The TI information was searched for in the financial statements published by the publicly traded companies that were the subject of the study, however these companies did not disclose the value of TI. Financial statements from 2002 to 2013 were analyzed for the 130 randomly chosen publicly traded companies.

The taxable income calculation using current income tax expense information may contain measurement errors for three main reasons, namely: (i) current income tax expenses may not represent companies' real taxable liabilities; (ii) the value for TI obtained via the extrapolation of current income tax may result in an imprecise estimate in cases in which companies have tax credits the effective tax used for the calculation of income tax is different to the maximum rate and in cases of companies with tax losses; and (iii) the reconciliations of the sources of differences between TI and AI are not standardized and, in most companies, are not disclosed (Hanlon, 2003).

Even though extrapolation of TI is not the ideal measure, this proxy has been used in previous studies (Lev \& Nissim, 2004; Hanlon, 2005; Frank et al., 2009; Comprix et al., 2012; Nakao, 2012; Costa, 2012). Moreover, the inclusion of more control variables, beyond those originally proposed by Tang (2006) - as well as the existence of the lagged dependent variable in the models, which were estimated for fixed effects, which control effects that are constant over time - softens the potential specification problem: omitted variables and measurement errors in the independent variables.

For future studies we suggest: (i) carrying out a study together with investors and analysts in order to capture the perception of these economic agents regarding the tax information disclosed by companies; (ii) testing other proxies for the quality of accounting information, such as conservatism, timing, and earnings management; (iii) including the share liquidity variable, which will make it possible to evaluate whether there is a difference in the impact of BTDs on more and less liquid shares; and (iv) using other methodological approaches to include the before and after of IFRS in Latin American countries. 


\section{References}

Atwood, T. J., Drake, M. S., \& Myers, L. A. (2010). Book-Tax Conformity, Earnings Persistence and the Association Between Earnings and Future Cash Flows. Journal of Accounting and Economics, 50, 111-125.

Ayers, B. C., Laplante, S. K., \& Mcguire, S. T. (2010). Credit Ratings and Taxes: The Effect of Book-Tax Differences on Ratings Changes. Contemporary Accounting Research, 27(2), 359-402.

Barth, M. E., Beaver, W.H., \& Landsman, W.R. (2001). The relevance of the value-relevance literature for financial accounting standard setting. Journal of Accounting and Economics, 31(1-3), 77-104.

Barth, M. E., Landsman, W. R., \& Lang, M. H. (2008). International accounting standards and accounting quality. Journal of Accounting Research, 46(3), 467-498.

Baum, C. (2006). An introduction to modern econometrics using Stata. Texas: Stata Press.

Blaylock, B., Shevlin, T., \& Wilson, R. J. (2012) Tax avoidance, large positive temporary book-tax differences, and earnings persistence. The Accounting Review, 87(1), 91-120.

Comprix, J., Graham Jr. R. C., \& Moore, J. A. (2011). Empirical evidence on the impact of book-tax differences on divergence of opinion among investors. Journal of the American Taxation Association, 33(1), 57-78.

Costa, P. S. (2012). Implicações da Adoção das. IFRS Sobre a Conformidade Financeira e Fiscal das Companhias Abertas Brasileiras. Tese (Doutorado em Controladoria e Contabilidade: Contabilidade) - Faculdade de Economia, Administração e Contabilidade, Universidade de São Paulo, São Paulo.

Costa, T. A., Silva, A. H. C., \& Laurencel, L. C. (2013). Escolha de práticas contábeis: um estudo sobre propriedades para investimento em empresas brasileiras não financeiras de capital aberto. Revista de Contabilidade e Organizações, 18, 25-36.

Cullinan, C. P. (1999). International Trade and Accounting Policy Choice: Theory and Canadian Evidence. The International Journal of Accounting, 34(4), 597-607.

Desai, M. A. (2005). The Degradation of Reported Corporate Profits. Journal of Economics Perspectives, 19(4), 171-192.

Frank, M. M., Lynch, L. J., \& Rego, S. O. (2009). Tax Reporting Aggressive Ness and its Relation to Agressive Financial Reporting The Accounting Review, 84(2), 467-496.

Guenther, D. A., \& Young, D. (2000). The association between financial accounting measures and real economic activity: a multinational study. Journal of Accounting and Economics, 29, 53-72.

Hanlon, M. (2003). What Can We Infer About a Firm's Taxable Income from its Financial Statements? National Tax Journal, 56(4), 831-863

Hanlon, M. (2005). The Persistence and Pricing of Earnings, Accruals and Cash Flows When Firms Have Large Book-Tax Differences. The Accounting Review, 80(1), 137-166.

Hanlon, M., \& Slemrod, J. (2009). What does tax aggressiveness signal? Evidence from stock price reactions to news about tax shelter involvement. Journal of Public Economics, 93, 126-141.

Heltzer, W. (2009). Conservatism and Book-Tax Differences. Journal of Accounting, Auditing \& Finance, 24(3), 469-504.

Jaafar, A., \& McLeay S. (2007). Country Effects and Sector Effects on the Harmonization of the Accounting Policy Choice. Abacus, 43(2), 156-189.

La Porta, R., De-Silanes, F. L., \& Shleifer (2008). A. The Economic Consequences of Legal Origins. Journal of Economic Literature, $46(2), 285-332$

Lev, B., \& Nissim, D. (2004). Taxable income, future earnings, and equity values. The Accounting Review, 79(4), 1039-1074.

Meyer, J. W., \& Rowan, B. (1977). Institutionalized Organizations: Formal Structure as Myth and Ceremony. American Journal of Sociology, 83(2), 340-363.

Nakao, S. H. (2012). A adoção de IFRS e o Legado da Conformidade Mandatória Contábil- Fiscal. Tese (de Livre Docência) Faculdade de Economia, Administração e Contabilidade, Universidade de São Paulo, Ribeirão Preto

Qiang, X. (2007). The effects of contracting, litigation, regulation, and tax costs on conditional and unconditional conservatism: crosssectional evidence at the firm level. The Accounting Review, 82(3), 759-796.

Shackelford, D., Slemrod, J., \& Sallee, J. (2011). Financial reporting tax, and real decisions: toward a unifying framework International Tax and Public Finance, 18(4), 461-494.

Tang, T. (2006). The Value Relevance of Book-Tax Differences - An Empirical Study in China's Capital Market. SSRN.

Tang, T., \& Firth, M. (2012). Earnings Persistence and Stock Market Reactions to the Different Information in Book-Tax Differences: Evidence from China. The International Journal of Accounting, 47, 369-397.

Tang, T. (2014). Does Book-Tax Conformity Deter Opportunistic Book and Tax Reporting? An International Analysis. PAPER University of British Columbia Faculty of Management.

Yoon, S. W. (2008). An International Study of the Relation Between Book-Tax Conformity and the Value Relevance of Earnings Components. Journal of International Business Research, 7(2), 31-56.

Weber, D. P. (2009). Do Analysts and Investors Fully Appreciate the Implications of Book-Tax Differences for Future Earnings? Contemporary Accounting Research, 26, 1175-1206.

Wilson, R. J. (2009). An examination of corporate tax shelter participants. The Accounting Review, 84(3), 969-999.

\section{Correspondence Address:}

Alessandra Vieira Cunha Marques

Faculdade de Ciências Contábeis, Universidade Federal de Uberlândia

Avenida João Naves de Ávila, 2121 - CEP: 38400-902

Campus Santa Mônica - Uberlândia - MG

Email: alessandra1909@hotmail.com 